\title{
China
}

\section{State power versus the Internet}

\author{
Willy Wo-Lap Lam
}

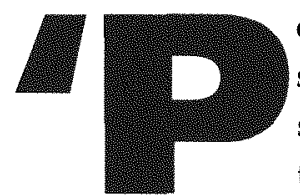
ower grows out of the barrel of a gun'. said Chairman Mao Zedong on the success of the Communist Revolution. Yet it is equally accurate to say that power grows out of, and is sustained by, the nib of a pen. Propaganda, through the heavy-handed manipulation of the media, has been just as essential as the army and police in upholding the mandate of heaven of the Chinese Communist Party (CCP). As China celebrated the 50th anniversary of Communist rule on 1 October 1999, the administration of President Jiang Zemin seemed to have barely deviated from the view that propaganda remains essential in promoting uniformity of thinking and support for the state, despite the telecommunications revolution which has transformed the global media.

More than the leaders of other communist and socialist countries, CCP chieftains have taken, and continue to take, a personal interest in propaganda. Mao himself was responsible for widespread pamphleteering before the Communist triumph in 1949. Then, from the early 1950 s to the end of the Cultural Revolution in 1976, the media was used to build faith in the Communist utopia and the vision that China could 'overtake' the United States and the United Kingdom in 20 years. After Deng Xiaoping launched the reformist open-door policy in 1978, the theme of the official media was how to mix socialism with market reforms. In the wake of the Tiananmen Square massacre and following the dissolution of the Soviet Bloc in the 1990s, the leadership used the press to shore up faith in the CCP and to counter the 'infiltration' of 'bourgeois-liberal' ideas. Under the leadership of President Jiang it seems unlikely that the 'traditional' functions of the Chinese media, such as promoting cohesion among the Chinese people and denigrating western values, will change in the new 
millennium. In fact, President Jiang appears to be building his own quasiMaoist personality cult. Calls in the press for patriotism and cohesiveness are thinly disguised attempts to promote the present leadership, with Jiang at its core.

Regardless of the prevailing view within the $\mathrm{CCP}$, the crucial question facing China is how long the quaint Communist party 'reading groups' of censors, the vague media laws and regulations which encourage selfcensorship, and the more blatant controls such as intimidation, arrest and imprisonment of journalists can hold back the tide of information technology. Already, the Internet is making significant inroads by linking dissident networks, and forcing the security apparatus into a seemingly futile race to try to stay one step ahead of a technology which allows new web sites to be opened and closed on a daily basis. At the same time market economic reforms are introducing new forces into the media. As government handouts decline, the media is being forced to make marketdriven changes, adding racy stories on issues such as crime, smuggling and prostitution to lure readers. More broadly, the market place is facilitating the rise of civil society. Despite the CCP's dogged refusal to share power, non-party civic organisations have proliferated. The role the media might play in ending the one-party state in China, and how far off or how inevitable that demise may be, is a critical challenge for President Jiang and his fellow septuagenarian leaders.

\section{Within the official birdcage}

Media watchers in China believe it is unlikely the CCP's official straightjacket will loosen in the near future, given the freeze on political reform which followed the crackdown of 4 June 1989. The Chinese media's reporting of the Balkan crisis in the spring of 1999, particularly the bombing of the Chinese embassy in Belgrade, provides a good example of recent CCP-style propaganda. According to the Chinese media, the 'Washingtonled NATO military machine' was trying to subjugate first Serbia, and then the rest of the world using the new doctrine of international humanitarianism. Ethnic cleansing carried out by the regime of Yugoslav President Slobodan Milosevic rated only a passing mention. The apology by US President Bill Clinton following the bombing of the Chinese embassy on the night of 7 May 1999 by NATO forces was not reported for two 
days. Then the press fanned anti-US feelings as students and citizens protested outside US missions across the country and played a key role in stirring up nationalism and pressuring America and other NATO countries. But, all mention of the embassy bombing suddenly disappeared from the Chinese media towards the end of July, when the regime decided it was time to revive ties with the United States in an effort to rein in the 'pro-independence gambit' of Taiwan President Lee Teng-hui.

During the 1990s, there were several timid initiatives in press liberalisation. The most recent was the brief 'Beijing spring' of mid 1998, in the run-up to President Clinton's visit to China. At that time the administration was reportedly considering allowing intellectuals to form political parties. Chinese and diplomatic sources in Beijing cited internal papers written by $\mathrm{CCP}$ think-tank liberals recommending permission be granted for the establishment of a non-Communist Party and non-official publications. But behind the scenes the liberals lost. Following the Clinton visit there was a new clampdown on dissent and mass arrests of dissidents. Censorship was tightened considerably and observers anticipate that this phase of conservatism will last at least through to 2002, or the end of Jiang's term as Party General Secretary.

But, even against this relatively bleak backdrop, subtle but highly significant changes are taking place. Some of the momentum is coming from within the CCP itself-but more significant pressures are building due to market economic reforms and the expansion of civil institutions. In this environment the CCP has called on the media to assist in Beijing's goal of limited reform: small-scale, within-the-establishment changes such as cracking down on corruption and mal-administration within the framework of one-party dictatorship. Newspapers cannot call for the birth of a new political party, but they can place the spotlight on corruption cases which do not threaten the single party state.

A major development in 1998 and 1999 was the call by senior cadres for the press to play a more effective watchdog role, particularly in uncovering crimes committed by officials. Relatively liberal cadres argued that in the absence of an opposition party, the press should have the task of scrutinising government. Even conservative cadres recognised the media's role in blowing the whistle on corruption. Such calls were made by leaders as different as Premier Zhu Rongji and National People's Congress (NPC) Chairman Li Peng. In late 1998, Li said 'We must better 
foster the media's power to supervise [government operations]...We must expose outstanding cases which severely infringe upon the law so that the cadres and the masses can be educated'. The former premier even asked the media to do its part in the 'construction of democracy and the legal system' and in fostering the ideal of 'running the country according to law' (China News Service 12 December 1998).

But, there can be no mistaking the proverbial birdcage. As Li hinted, the media could only expose certain designated cases sanctioned by the authorities. Throughout China, the prosecution and reporting of corruption by senior officials requires approval at the highest levels of $\mathrm{CCP}$. For cases involving officials with the rank of vice-mayor, vicegovernor or vice-minister, or above, authorisation by CCP Central Committee's Central Commission for Disciplinary Inspection is needed. Effectively, the media requires the nod of national or local-level propaganda departments before it can run stories on the misdemeanours of senior officials.

Taboos, mostly unwritten ones, are too numerous to detail. News blackouts are imposed on embarrassing events such as labour unrest or protests by overtaxed peasants. The same goes for the anti-government activities of pro-independence elements in Tibet or Xinjiang. Journalists are not allowed to play up political reform, except such innocuous exercises as administrative streamlining and boosting public consultation. Calls for accelerated democratisation or the dilution of the CCP's monopoly of power are clearly off limits. Generally, the media is discouraged from dwelling on the dark side of society, a reference to negative phenomena including the brain drain to western countries, suicide rates, prostitution and homosexuality.

Changes, however, are taking place in spite of the CCP's strictures. The economy is the most significant force for change. The late patriarch Deng Xiaoping and his disciples, such as Premier Zhu, realised that the development of the market economy would chip away at the authority of the CCP. But this was the price to pay for developing the economy. One key conclusion Deng drew from the dissolution of the Soviet Union was that if the people's standard of living was not improved, the regime's mandate of heaven would be in tatters.

To some extent the same applies to the media. Because the free flow of news and ideas is essential to the development of an information-based 
economy, more cadres have come to accept that the floodgate must be slowly opened (Straits Times, 13 June 1999 and 27 February 1999). There is also the economic reality that the state media must become financially self-sufficient. Facing bulging budget deficits, the administration of Jiang and Zhu has tried to end the media's dependency on government handouts. With declining Party or government subsidies, the media must appeal to the marketplace to survive-and turn up profits! Sensational stories on crime and prostitution are pushing out the boundaries, without trespassing on sensitive political issues in afternoon tabloids that rival the raciest of Hong Kong's scandal sheets.

Also significant is the rise of civil society and the role of the Internet. While the CCP maintains a monopoly on political power, there is growth in non-party, civic organisations, from consumer-protection associations and chambers of commerce, to semi-clandestine outfits associated with cults and gigong sects. While most associations are not permitted to produce their own publications, they have contributed to a more pluralistic society and media. With the growth of the Internet, civic associations can air their own views on websites. One reason behind the crackdown on the enormously popular Falun Gong sect, a Buddhist-cum-qigong organisation, in mid 1999 was its ability to mobilise tens of thousands of followers via the Internet (Agence France-Presse, 22 July 1999).

\section{The yoke of orthodoxy}

China's government-controlled media now reaches deep into society. Eighty-eight per cent of Chinese have access to the network of 932 television stations and 86 per cent of the population is served by 1,623 radio stations. Three-hundred and five million households own a television set, and with plummeting retail prices due to industrial overproduction two television households are becoming more common (Reuters, 23 December 1998). For news, rather than entertainment, the 2,160 newspapers and 7,900 periodicals are still considered the main source of information.

Despite official efforts to separate the government from the direct control of businesses, most media outlets are official organs or subordinate units of the CCP and government organisations. All heads of key media units are appointed by the CCP Central Committee's Organisation 
Department, or its local equivalent, and all report to the various propaganda departments of the CCP. The People's Daily and Outlook Weekly, for example, are mouthpieces of the CCP Central Committee. The China Youth Daily reports to the Communist Youth League and the Workers Daily is a subsidiary of the official-and only-trade union, the All-China Federation of Trade Unions (Fan Li 1999). Every newspaper, magazine and radio or television unit is sponsored by an appropriate unit of the $\mathrm{CCP}$ or the government.

In this way internal ideological and power struggles can be played out through the media. The Nanfang Weekend, a subsidiary of Nanfang Daily, and the mouthpiece of the Guangdong Province Party Committee was repeatedly disciplined by the central Propaganda Department in the mid 1990s for its exposition of the darker side of society. The paper became a symbol of the unending tug of war between the zhongyang (central authorities) and local authorities. At the time the paper was protected by former Guangdong party secretary Xie Fei, a relatively liberal official. In September 1997, however, Xie was replaced by the hardline Li Changchun, who towed the Beijing line far more closely. By 1999, Nanfang Weekend's muckraking had declined and a number of the most senior journalists had resigned.

The marketplace, too, has offered journalists new and innovative loopholes to circumvent the zhongyang line. As the tide of commercialisation began sweeping the nation in the mid 1990s, more CCP and government departments offered 'official sponsorship' to new newspapers or magazines for a fee. In this way a group of free-thinking editors who wanted to start a quasi-private publication could pay the fee to qualify as the subsidiary of, for example, a mediocre, provincial-level research institute. After pocketing the money, the institute would usually turn a blind eye to the contents of the publication. However, much of the efforts of the censors are now targeted at these small publications (Reuters, 29 January 1999).

Access to foreign publications is limited by a government monopoly on imports which uses quotas to control the circulation of papers such as the Asian Wall Street Journal, the International Herald Tribune and the South China Morning Post. Import quotas limit each publication to not more than 10,000 copies and censors can ban entire daily consignments if, for 
example, the edition carries a picture of the Dalai Lama or Taiwan President Lee Teng-hui.

New chinks in the armour of official censorship are more evident in television despite the CCP's determination to guard the airwaves against subversive foreign programs as zealously as it does its air space against enemy aircraft. With minor exceptions, foreign satellite broadcasts are not available to ordinary Chinese. In 1993 and 1994, the government introduced regulations to forbid individual households from setting up satellite dishes to get programs from Hong Kong, Taiwan, Japan or the United States. CNN and BBC TV are only available to hotel patrons (The Times, 5 June 1999). However, the official CCTV, which has nine channels reaching the homes of 900 million people, is planning a major marketing launch of satellite television. There are indications more foreign entertainment programs will be permitted. In 1998 and 1999 Rupert Murdoch's News Corp., the MIH Group of South Africa, and Encore International, a subsidiary of the American cable TV company $\mathrm{TCl}$, all gained initial footholds with one-off sales of entertainment programs or documentaries. The Hong Kong-based Phoenix TV, partly owned by Murdoch, is the only foreign satellite broadcaster with regular access to sizeable chunks of the urban population, at times broadcasting news programs containing material not deemed politically correct by the Chinese censors (Reuters, 5 August 1999).

The rapid spread of cable TV will also add variety to the official fare. As of early 1999, there were more than 1,000 cable stations, mostly at municipal or county level. Each network transmitted an average of 20 channels (Brent 1998). China's large state-owned enterprises, which often employ more than 100,000 staff, also run their own cable stations. These cable companies often buy entertainment programs from Hong Kong and other parts of Asia, and occasionally broadcast news and documentaries, particularly in relatively liberal cities in Guangdong.

Can a hundred flowers bloom in the 21st century? Mao's 1950s' slogan was actually used to lure assorted 'anti-party elements' to speak their minds to provide the state security apparatus with enough evidence to jail them. It is particularly relevant for President Jiang. The head of the so-called Shanghai Faction in Chinese politics and considered more conservative than Deng in ideological matters, he has reinstated a number 
of Maoist norms (Xin 1996). To understand media policy in fin de siecle China, it is important to study the concerns of Jiang and his associates.

More than his former mentor Deng, Jiang holds the Maoist viewpoint that the CCP must have a tight grip on the pen. Jiang is fond of proclaiming that the media must be in the hands of 'trustworthy Marxists who are loyal to the party' (People's Daily, 16 October 1999). Jiang's views on the media and propaganda were expounded during his landmark visit to the People's Daily in September 1996. He stated that '[t]he work of the media is ideological and political work-on which the future and fate of the $\mathrm{CCP}$ and country lie'. Jiang identified promoting the zhongyang line and maintaining socio-political stability as the media's key tasks. Or as the quasi-Maoist director of People's Daily, Shao Huaze said, 'Journalists should increase their capacity to distinguish between political rights and wrongs. There must be no ambiguity over the crucial principle of the Party's leadership over the media and the role of the media as the mouthpiece of the Party' (Agence France-Presse, 29 October 1999). As Propaganda Chief Ding Guan'gen sees it, the rightful role of media is to 'resolutely develop the leitmotif of patriotism, collectivism and socialism; and to combat the influence of corrupt and decadent thoughts' (Sing Tao Daily News, 16 June 1997).

The media was asked to steer clear of taboo subjects, ranging from scandals involving senior cadres to apparently innocuous subjects such as casualties from fires and floods. History, too, was manipulated with a 1996 ban on the press carrying commemorative stories to mark the 30th anniversary of the start of the Cultural Revolution. On the 80th anniversary of the May Fourth Movement, which first introduced western theories of democracy to China, publication units were told not to dwell on the liberal aspects of what became known as the Chinese Enlightenment (Ming Pao, 12 June 1999 and 20 November 1998). One of the most disturbing aspects of the Chinese media in the late 1990s, however, was the emergence of a quasi-Maoist personality cult around Jiang. Far more than previous leaders (including Deng), Jiang often monopolised the first three to four minutes of the nightly CCTV news. His speeches to officials, People's Liberation Army soldiers, model workers and peasants were reported in great detail, and touted as must-read material in ideological sessions. The President's minders made use of all media opportunities to show that the core of the third generation leadership was in control (Lam 1999). 
The media policy of Premier Zhu, widely considered the Politburo member most in tune with the new century, is worth assessing as it illustrates the most basic CCP contradiction in its attitude to the media. A cadre may have a liberal track record in economic reform, but he may still subscribe to the quasi-Maoist view that the media should serve the political ends of the CCP. Not unlike President Jiang, Zhu is a talented manipulator of the media. During recent trips abroad, his aides paid special attention to coverage in the local media, including Chinese-language papers in countries with sizeable Chinese communities such as the United States, Canada and the United Kingdom. Zhu regularly made himself, or at least some underlings, accessible to the press. During his visit to the United States in April 1999, the few dozen Hong Kong journalists covering the premier complained that they had been given no access. The same day, his spokesman, scheduled an extra briefing for the Chinese-speaking press.

Zhu made many friends among the press in 1998 when he toured the studios of CCTV and talked to the journalists responsible for the news magazine program In Focus. 'Supervision by the media is very important', the premier said, '[P]ress supervision can correct the mistakes of our work and reflect the voice of the masses'. Zhu praised the journalists for having 'overcome many problems', perhaps an allusion to the fact that many government departments had blocked their work. He instructed the media to play a catalyst role for party and government policies (New China News Agency, 7 October 1998). But while Zhu likes to present himself as a patron of the media, he has also made it clear his support depends on not trying to second-guess the zhongyang line. Take, for example, the economic tsar's well-known views about not devaluing the renminbi, or the virtues of joining the World Trade Organisation (WTO). From 1997 onwards, official papers and journals were not permitted to carry the articles of scholars who advocated renminbi depreciation. Nor were the media allowed to air the views of the anti-WTO lobby after Zhu decided to move faster on the accession issue in early 1999 (Zhengqin 1998).

\section{Hazards for joumalists}

While the ideal of 'rule of law' was enshrined first in the CCP charter in 1997 and then in the State Constitution in 1999, efforts to promulgate the nation's first journalism or publication law have been repeatedly 
postponed. Early versions of the law, drafted in the relatively open mid 1980 s, borrowed elements of similar laws in the west. One key player, the liberal former editor of the People's Daily, Hu Jiwei, travelled to the Shenzhen special economic zone to exchange views with Hong Kong editors and journalism scholars. While upholding the overall theory of party guidance, the early drafts stated that a publication unit or journalist could only be penalised under clear-cut criteria such as endangering national security or libelling the CCP and cadres. They also acknowledged the journalists' rights to report the news in a truthful manner. The brief thaw of 1997 and 1998 revived pressure to enact media laws, but by mid 1999 they had been mothballed.

The absence of clear-cut laws has left many journalists frustrated and vulnerable to the whims of CCP officials. 'We often feel uncertain when we are dealing with tortuous news events, especially in investigative reporting', Workers' Daily senior editor Wang Xiaolong said in 1998. 'There should be a law to define what the media can and cannot do' (Agence France-Presse, 18 August 1998). This confusion, of course, can be used to the $\mathrm{CCP}^{\prime} \mathrm{s}$ advantage. Without the protection afforded by a media law, journalists are left exposed to a plethora of draconian statutes and government practices. Most Chinese journalists, as well as foreign journalists based in China, live and work in fear of violating laws on state secrets or national security. The State Secrets Law (1988) and the Maintenance of State Secrets Law Implementing Procedures (1990) have given Party and government units, such as the Ministry of State Security and the State Bureau for Protecting Secrets, maximum flexibility in incriminating journalists. For example, Article 2 of the State Secrets Law defines state secrets as 'matters that affect the security and interests of the state, knowledge of which ... is restricted to personnel within certain limits for a definite time'. Such secrets include 'major policy decisions on state affairs', as well as classified material relating to defence, diplomacy, industry, science and technology (Fu and Cullen 1996).

As veteran journalists delight in pointing out, however, 'whatever has not appeared in the People's Daily can be considered state secrets'. There is no freedom of information act, nor any tradition of the public's right to know, increasing hazards for journalist. In facing litigation, reporters accused of leaking state secrets cannot cite the public interest in selfdefence. 
In the 1990s, scores of domestic and foreign journalists were detained or harassed for alleged breaches of the state secrets codes. Breaches sometimes amounted to no more than running draft versions of speeches due to be delivered by senior cadres or disclosing trade or commercial information. Foreign, Hong Kong and domestic journalists have all been subject to the arbitrary imposition of legal sanctions. However, while western correspondents are expelled from China and Hong Kong reporters receive short jail sentences, Chinese journalists may be severely punished. New China News Agency (NCNA) journalist Wu Shishen, for example, was given a life sentence for making available to a Hong Kong paper an advance copy of the speech Jiang delivered at a Party Congress in 1992. By contrast, the Hong Kong journalist who allegedly bought the material from Wu was let off after a brief detention.

Laws on defamation and related judicial procedures are also open to abuse. Article 101 of the Civil Law General Principles enshrines a citizen's right to his good reputation and provides legal protection against insults, libel and other means used to damage a person's good name. Defamation of a political nature can be dealt with under Article 105 of the Criminal Law. The statute says it is a crime to instigate the subversion of the political power of the state and the overthrow of the socialist system through spreading rumours, slandering or other ways' (Goodale 1999). A number of dissidents and avant-garde journalists have been successfully sued and punished for libelling the state. On the other hand, state media are usually protected from defamation charges or lawsuits when they carry reports of the supposed crimes of dissidents. Prominent dissident Chen Ziming attempted to sue the CCP's Propaganda Department, the NCNA and People's Daily for libel over a report stating he had 'participated in and directly commanded' attacks against martial law troops in 1989. The courts refused to hear the case (Schlesinger 1992).

While the regime believes it must maintain the ideological barricades against hostile foreign forces, it is unlikely Beijing will allow foreign media outlets to circulate or broadcast in China, or establish joint ventures with local outlets. As of mid 1999, only a handful of foreign magazines specialising in non-political subject matters, such as Elle, Figaro and Cosmopolitan, have been permitted to publish Chinese editions with official publishing units. Why certain foreign publications are allowed to establish footholds and others are not is neither officially explained nor subject to 
any policy guidelines. It is assumed that a Politburo-ranked official must approve politically sensitive joint ventures. Evidently the personal permission of Politburo member in charge of propaganda, Ding Guan'gen, was given for the Shenxing Daily, a joint venture between a Shenzhen official unit and Hong Kong's Sing Tao Group. The paper, however, looks and reads much like a mainland paper. Efforts by other foreign or Hong Kong dailies to set up mainland-based papers have all been unsuccessful.

Those foreign news companies which have secured a significant foothold in China, have invested considerable financial resources in the trust of leaders. Rupert Murdoch's News Corp., for example, has a 45 per cent stake in the Hong Kong-based Phoenix Satellite TV. Phoenix carries a mixture of racy entertainment and normally non-controversial news programs. According to his critics, Murdoch declared his good intentions by publishing an official biography of Deng Xiaoping, and scrapping plans by a subsidiary book company to publish East and West by former Hong Kong Governor Chris Patten. But it is no coincidence that on sensitive occasions, such as the run-up to the tenth anniversary of Tiananmen Square in 1999, signals for Phoenix are muffled, as are those of CNN and BBC which are in any case only available in hotels or foreigners' compounds.

\section{Blitz against the media}

Without western-style laws, media control is exercised mainly in the form of ad hoc notices, secondary regulations and administrative practices. One of the easiest methods is simply to cut down the numbers. To trim real and potential poisonous weeds, a wave of newspapers, magazines and television stations closures began in the mid 1990s, in the name of shrinking the budget deficit. From 1995, the State Press and Publications Administration stopped issuing licences for new newspapers and publishing houses and in mid 1996 applied the same principle to radio and TV. In-house newspapers and magazines run by the CCP and government departments were slashed. In late 1996, then Vice-Premier Zhu Rongji ordered the closure of dozens of newspapers sponsored by the state banking system (Singer 1997). As well as outright closures, Beijing concocted other innocuous sounding policies to prevent a hundred flowers from blooming. One was a massive merger initiative, swallowing existing 
publications into six mammoth media conglomerates: three in Guangzhou, two in Beijing and one in Shanghai (Reuters, 4 August 1998). A key theme of the reform of state-owned enterprises was to form conglomerates along the lines of the Japanese zaibatsu and the South Korean chaebol. The creation of conglomerates makes it easier for the authorities to exert control.

Dozens of politically incorrect magazines and publishing houses were closed down in the late 1990s. It is important to note that given the state's largely successful control of the underground opposition, publications by clandestine organisations similar to samizdat in the Soviet Union were almost non-existent. The media units axed were relatively tame intellectual journals that never opposed the CCP directly. They ran foul of Beijing for espousing relatively radical views on political or cultural modernisation. For example, the Beijing-based Oriental Monthly was disciplined in 1997 and 1998 for running articles on ways to learn the lesson from the Cultural Revolution. Both The Way of Beijing and Cultural Times of Guangzhou were closed down in 1999 merely for advocating an open attitude towards western values and a faster pace of reform (Agence France-Presse, 15 January 1999).

According to watchdog units such as the New York-based Committee to Protect Journalists, the CCP administration is among the world's worst offenders for incarcerating reporters. In the summer of 1998, Shi Binhai, an investigative reporter with the China Economic Times, was detained for almost one year for conducting private interviews with ousted party chief Zhao Ziyang. Shi's case was never brought to public trial. Not a word about his fate ever appeared in the official media. Gao Yu was locked up in 1994 for allegedly leaking state secrets in the course of writing articles for Hong Kong publications. Gao had to serve her full five-year term despite numerous petitions by foreign governments and human rights organisations (Agence France-Presse, 28 March 1999).

Censorship in Beijing remains much the same now as it was in the 1950s, even as China is gearing up to launch its first satellites in 2001 and 2002. Proofs of the front page of the People's Daily have to be approved by a senior Propaganda Department bureaucrat, usually Politburo member Ding, the night before publication. A 'reading group' in the department consisting of censors and ideologues pore through major papers every day in search of violations of $\mathrm{CCP}$ discipline. During national festivals 
such as the 1 October National Day or 1 August Army Day, media publish the requisite feel-good messages from relevant authorities. At times of crises such as the confrontation with Taipei in 1995-96 and 1999, newspapers and television dutifully performed the role of agents for psychological warfare. Newspapers and TV stations nationwide must follow the NCNA wire when reporting on the activities and speeches of leaders.

The same tight control is exercised over the more than 100 foreign reporters based in China. Despite much-improved communications with the outside world, Beijing still sees the foreign media as no more than an adjunct of their governments - even as secret agents. This is perhaps a reflection of the fact that many Chinese foreign correspondents are much more than journalists; they also file internal reports to leading Party and government departments. Following the NATO bombing of the Chinese embassy in Belgrade, the US media claimed that two of the three journalists killed were in fact intelligence officers. This was denied by the Chinese Foreign Ministry.

The leadership's control of western correspondents has not changed greatly since the late 1970s, when the first batch of foreign reporters was granted residency visas for Beijing. By the mid 1990s, news bureaux could be opened in Shanghai and Guangzhou but the supervisory mechanism remains draconian. Journalists who want to conduct interviews must first apply to the foreign affairs bureau of government offices, factories or colleges. Correspondents who want to leave their bases and report in other provinces must first seek the approval of relevant local authorities. Many of the more active correspondents are subject to surveillance by state security agents on a daily basis. Taboo areas for foreign journalists include Beijing's treatment of dissidents and human rights in general, the underground church, and events in Tibet and Xinjiang. Throughout the 1990s, an average of one foreign reporter per year was expelled for reasons such as leaking state secrets. In 1998, the reporter for Japan's Yomiuri Shimbun, Yukihisa Nakatsu, was forced to leave for allegedly handling Party documents considered to be classified information. The same year, the accreditation of Juergen Kremb, the veteran correspondent for the German magazine Der Spiegel, was abruptly cancelled, apparently for his work on dissidents including Wei Jingsheng (Agence France-Presse, 7 October 1998). 


\section{Forces for change}

The administration of President Jiang and Premier Zhu seems determined to pursue cautious economic market reforms while continuing the deep freeze on political liberalisation at least until 2002 or 2003, when they are due to retire from the front line. The real changes in media policy and practice, then, are likely to stem from non-party factors such as the marketisation of the economy, the emergence of civil society, the impact of the Internet, the impact of foreign influences-and the initiative of independent-minded journalists.

'You have your strategy, I have my counter-strategy.' This principle is often cited by local officials confident of foiling or at least diluting the zhongyang's strictures. Yet the slogan also describes in a vivid manner the ability of free-thinking publishers, authors and video producers to thumb their nose at authority.

Since the mid 1990s, rebel book merchants have launched effective guerrilla warfare underground against the censors. In 1998 an estimated 60 per cent of the book distribution market was controlled by non-official and illegal publishers and distributors. There are approximately 400 official publishing houses. These clandestine operators have high mobility. They use the services of printers from different cities. The underground publishers, producing pirated or unofficial publications, usually disappear once their products are given to underground distributors, who then make them available to street-level booksellers. During police crackdowns, street vendors do not openly display the taboo books, which are only sold to trusted customers. The motive for many underground publishers is to make profits, not to fight for political freedom. And, not surprisingly, many of the illicit books are pornographic. But, a significant proportion of underground titles are politically taboo such as pirated editions of books first published in Hong Kong and Taiwan. Perennial favourites include Li Zhisui's, The Private Life of Mao Zedong, the memoirs of Xu Jiatun (the former head of Beijing's mission to Hong Kong who defected to the United States in 1990) and unofficial biographies of politicians ranging from Zhou Enlai to Madame Jiang Qing (Ming Pao, 2 April 1999).

According to Chen Fang, author of the best-selling The Wrath of Heaven, the phenomenon of underground publishing is both a blessing and a curse. Official criticism of his book, a fictional account of the corrupt empire of 
the former Beijing party chief Chen Xitong, provoked wider interest in China. But, its distribution through book pirates and illegal networks deprived the author of most of the profits. Most liberal authors agree that clandestine channels have opened up much wider choices for China's readers, but at the expense of the author's livelihood.

China has caught on to the Internet. The number of surfers surged to more than four million in late 1999, compared to just 250,000 at the end of 1997. E-commerce and e-business are thriving. At the same time new online services such as Shanghai.online and Shenzhen.online are providing traditional media outlets with new competition. Most of them began by merely reprinting reports from newspapers, but gradually some have developed their own editorial material. Shenzhen.online, for example, now runs sensational social stories, ranging from robberies and murders to supermarket security strip-searching female customers, while staying clear of overtly political topics (Wall Street Journal, 18 January 1999). Most importantly, the Internet offers Chinese a window on the outside world.

Like other authoritarian governments in Asia, from the very beginning, China was aware of the destabilising influence of the Internet. Before Deng's demise in 1997, Propaganda Chief Ding was quoted as asking his experts whether the Internet could be grounded throughout China a day or so before the official announcement. In early 1996, Beijing required all Internet users to register with the police and later that year providers, who must be government-run or affiliated, blocked off some 100 sites. These included websites of the US Government, Hong Kong and Taiwan papers, as well as Voice of America and Radio Free Asia. Yet as the Chinese saying goes, '[W] hile the guardians of orthodoxy put up one foot [of resistance], the devils can up the ante by ten times'. Beijing has been unsuccessful in blocking the thousand and one sites that dissidents in the United States and other parts of the world are establishing. And on a daily basis, rebel intellectuals are downloading reams of 'offensive' material provided by overseas sympathisers (New York Times, 18 October 1998).

Consider the artful dodging perpetrated by the US-based VIP Reference, a 'subversive' Internet magazine that is being dispatched regularly to more than 300,000 e-mail addresses in China. Typical fare includes political news censored by the mainland media, information about dissidents, and 
stories about factional struggles within the leadership. The addresses, compiled from commercial and public lists, include those of public and state security units. To escape police detection, the New York and Washington-based organisers switch providers each day. 'We like the concept of free speech and we want a legal system to protect it', said Li Hongkuan, a Chinese intellectual based in New York who edits the magazine. '[W]e want to destroy the Chinese system of censorship over the Internet.' To protect Chinese readers, VIP Reference asks recipients not to forward the material to friends within the country (Flatin 1999).

The Internet also worries the CCP because it is a potent tool for political organisation-and agitation. The China Democracy Party credited its fast growth to the word being spread on the net. The same was true for the Falun Gong, and many of the edicts of its founder Li Honzhi reached the faithful in the mainland and overseas via their websites.

The Internet also has a powerful interactive function. During the Cultural Revolution, college students put up dazibao (literally big-character posters) on campuses to air their views. Electronic versions of the dazibao first appeared during protests against the Japanese 'occupation' of the Diaoyu or Senkaku islands off Taiwan in 1996 and 1997. By the time of the Belgrade embassy bombing incident, the use of the Internet as a vehicle to spread political opinion had become routine. Both college students and intellectuals are spreading politically incorrect ideas via computer screens. Even though the views expressed in Internet fora may sometimes be progovernment, Beijing is alarmed its lack of control over a medium that can powerfully shape people's thoughts.

In late 1998 the CCP struck back with a vengeance. In big cities, particularly those along the coast, police departments expanded their divisions dealing with security concerning electronic data and the Internet. In mid August, the Ministry of Information Technology and well as the Ministries of Public and State Securities published regulations asking all departments to upgrade their information technology security. Government departments were forbidden to link internal computer systems to those outside the offices. Beijing also rushed through Regulations Governing the Security and Protection of Computer Information Systems. Among other things, the rules prohibited Internet activities that undermine the interests of the state and the legal interest of 
other citizens (Smith 1999). Huge sums of money were spent on importing foreign Internet-nanny techniques, such as filtration systems to block or catch offensive websites and data.

In January 1999, Lin Hai, a computer engineer in Shanghai, was sentenced to two years in jail for providing VIP Reference with a database of 30,000 addresses. Lin's wife, who was not allowed to attend the trial, said her husband had no interest in politics (Langfitt 1999; Asian Wall Street Journal, 19 January 1999). Police have been able to crack several Internet political journals published within China. The organisers of Public Opinion, whose contents were similar to those of VIP Reference, went into hiding in early 1999 (Farley 1999).

Yet technology is fast outpacing the regulators and police. There has been a reasonably long time gap of at least several months if not a year or two between the arrival of new Internet technology and a new regulation forbidding its use. Most importantly, excessive control could stifle scientific development and economic growth. Knowledge of the information superhighway is critical in understanding and accessing tomorrow's technology. As early as 1996, the China Daily pointed out that 'the value of the Internet so outweighs its potentially harmful aspects-pornography and politically destructive information - that the Chinese government has approved its opening to the public' (Lam 1999). At least along the coast, the Internet had, by mid 1999, become a formidable rival to the government propaganda machinery.

\section{Looking toward the new millennium}

During his memorable tour of CCTV, Premier Zhu praised reporters for being 'the mirror of government [work] and the forerunners of reform' (New China News Agency, 7 October 1998). But, witness the thousands of editors and reporters who joined the students at Tiananmen Square during the six weeks prior to the crackdown. After the troops marched into the Square, dozens of journalists were detained for abetting if not masterminding the pro-democracy movement. Believing that time is hardly ripe for a major step forward, most of these avant-garde journalists have since kept a low profile. But in China media workers do have a unique role in expanding pluralism, if not in promoting democratisation itself. In the former Eastern Bloc, alternate power centres such as the church and 
trade unions were instrumental in the fall of the Berlin Wall and the dissolution of the Soviet state. Since 1949, however, the CCP has been the only source of authority in the country. Newspapers and television stations have, albeit in an embryonic way, served the purpose of varying the ideological landscape. Most of the new ideas which have reached urban areas, have been disseminated through the media, not other networks.

For two to three years before the 4 June 1989 crackdown, it was liberal papers such as the Shanghai-based World Economic Herald and the Beijingbased Economics Weekly that coupled market reforms being with westernstyle political freedom. Given the Jiang administration's tight control over the mainstream media, the relatively liberal papers of the late 1990s were most remarkable for their efforts in urging faster market reforms, particularly quasi-privatisation for small and medium state-owned enterprises. The Beijing-based China Economic Times and the Chongqingbased journal, Reform, have delved into more fundamental questions such as the need for institutional and political change to match economic reform. For example, China Economic Times was at the forefront of the small-scale liberalisation movement in the run-up to the 15th Party Congress. It advocated the development of a mixed economy and the shareholding system. Even after the post 1998 freeze, the paper concentrated on sensitive areas such as the failure of the government to live up to its commitment to devote at least four per cent of gross domestic product to education. Liberal economist Wu Jinglian argued in Reform that one lesson of the East Asian economic crisis of 1997-99 was that China must liberalise its system of governance, including through the separation of government and business (Reform, April 1998; South China Morning Post, 15 March 1999).

Sometimes, small-circulation papers in remote areas have had the courage to ask overwhelming questions. Take the case of Asia-Pacific Wind, a weekly newspaper based in Kunming, Yunnan Province. On 4 September, 1999 it reported the corruption case of the vice-mayor of Ningbo, Xie Jianbang, who took home at least 500,000 yuan and was responsible for economic losses of more than 900 million yuan. Xie was given a suspended death sentence, which in the Chinese context means he would be let off after a long jail term. In a commentary, Asia-Pacific Wind asked why many low-level officials were executed for pocketing much less money and doing much less harm (Asia-Pacific Wind, 4 September 1999). 
Books are also playing a significant role in political enlightenment in the late 1990s. Two publishing companies, Today's China Press and the Economic Daily Press, were instrumental in intensifying the debate on reform. Today's China Press published a highly influential series of books under the label, 'China's Problems'. Titles included Cross Swords, which chronicled the battle between reformers and leftists in the 1980s and 1990s, and The Trap of Modernisation, which criticised the administration for dragging its feet on reform.

Looking ahead at the new millennium, it seems likely that Fortress CCP cannot withstand the winds of change for long. Government propaganda has increasingly lost credibility: the circulation of the People's Daily and other traditional mouthpieces is declining fast, as more urban intellectuals have access to satellite television and, in particular, dissident websites. As Beijing-based media professor Hu Zhengrong pointed out, more people are living in a global village. 'As the economy and society become more globalised, the globalisation of broadcasting, television and communications is inevitable' (author's interview with Hu Zhengrong, 3 September, Kunming, China).

The pace of change is tipped to accelerate after China's accession to the World Trade Organisation. The development of the non-state sector of the economy will also provide the basis for a pluralistic society. President Jiang and his fellow septuagenarians are hanging on to power thanks to their control of the army and other 'tools of the dictatorship of the proletariat'. On the one hand, the CCP's apparent stranglehold over propaganda may help to extend its mandate of heaven. On the other, the growing diversity and irreverence of the alternative media is paving the way for the end of one-party dictatorship. 


\section{Appendix: Who's who of the leading print media?}

\section{Media}

People's Daily

Guangming Daily

Reference News

Economic Daily

Liberation Army Daily

China Youth Daily

Liberation Daily (Shanghai)

Nanfang Daily (Guangzhou)

Shenzhen Special Zone

Daily (Shenzhen)
Responsible person

Shao Huaze

Wang Shen

Xia Haitao

Ai Feng

Sun Zhongguo

Xu Zhuqing

Qin Shaode

Li Mengyu

Cheng Zengsheng

\section{Media websites}

China media network, www.guangmingdaily.com.cn/gbnn.htm/

People's Daily, www.peopledaily.com.cn/

Chinese Central Television, www.cctv.com/

Xinhua, www.xinhua.org/

Liberation Daily, www.jfdaily.com.cn/

China Democratic Party, www.freechina.net/edp/ (English edn)

Hong Kong Information Centre of Human Rights and Democratic

Movement in China, www.speednet.net/

Democracy and Justice Party, http://come.to/cdjp/

Tunnel Magazine, http:/ / home.talkcity.com/WallSt/suidao/

The Cardinal Kung Foundation, www.cardinalkungfoundation.org/

Falun Gong, www.falundafa.org/ 